\title{
Varied emplacement within adjacent kimberlite vents, Jwaneng Mine, Botswana
}

\author{
Martin A. Roberts ${ }^{1}$, K. (Major) Mmualefe ${ }^{2}$ \\ I Anglo American Corporation, London, UK, martinandrew.roberts@angloamerican.com \\ 2 Debswana, Gaborone, Botswana, k.mmualefe@debswana.bw
}

\section{Introduction}

The Jwaneng kimberlite occurrence comprise a series of adjacent kimberlite pipes ( $235 \pm 4 \mathrm{Ma}$, Kinney et al. 1989) within the Jwaneng kimberlite cluster in Southern Botswana. Recent drilling (totaling 57km of kimberlite intersection) within the Jwaneng Resource Extension Projects (2004-2013) has aided the review of the geological and emplacement models to a depth of $1000 \mathrm{~m}$. Three adjacent pipes: South, Centre and North pipes dominate the Jwaneng occurrence which represented a combined 54 ha area at surface at the time of discovery in 1972. Additional minor kimberlite bodies have been discovered during the stripping of overlying Kalahari sediments through progressive expansion of the Jwaneng open pit. Field relationships observed during early mining, demonstrated that South Pipe was partially truncated by Centre Pipe, with North Pipe showing no intersection with adjacent pipes. The age interpretation is that South Pipe preceded Centre Pipe which preceded North Pipe. The geology of Jwaneng has been previously described by Webb et al (2003) and Brown et al (2008) based on field evidence within the pit and earlier drilling programs.

\section{Characteristics across the pipes}

All the pipes erupted through the same pre-existing country rock geology which at surface was the Beaufort Group (Karoo) terrestrial sediments consisting of fluvial mudstones, siltstones and sandstones that were potentially underlain by minor Waterberg arkoses and poorly developed conglomerates no longer preserved. Below this is the thick sequence of Transvaal sediments with quartzitic shales overlying dolomites. Although the Karoo and Waterberg are no longer preserved in-situ today, the Karoo mudstones are well preserved as large blocks and smaller fragments within the kimberlite pipes. The shape of the mudstone fragments are often fluidal and this may suggest that the mudstones were wet at the time of the kimberlite emplacement. All three pipes are associated with steep ( $\sim 0$ degrees) and relatively smooth and sharp kimberlite/wall-rock contacts. Before the onset of mining, the upper portions of the pipes were dominated by reworked volcaniclastic sediments with shallow dipping bedding structures. This is underlain by the main pipe infill which is typically dominated by broadly massive volcaniclastic kimberlite (MVK) which is largely well mixed and with relatively few clasts $>10 \mathrm{~cm}$, with bedded pyroclastic and volcaniclastic units only preserved in the North Pipe. Common internal features across the three pipes include a sequence of rim units associated with local wall rock breccia and volcaniclastic units showing steeply inclined bedding and associated shearing. Large Karoo mudstone blocks are common within these units and are typically rotated and have moved downwards along the pipe margin (in places $>900 \mathrm{~m}$ below their in-situ stratigraphic level). The internal core units which volumetrically dominate the pipes, are associated with relatively low levels of country rock dilution (typically $<10 \%$ measured in fragments above $5 \mathrm{~mm}$ ). The resultant geometry of the pipes and infill characteristics (including the presence of PK and RVK and the absence of tuffisitic kimberlite) fall within the Class 3 kimberlites described by Skinner and Marsh (2004) and have strong similarities to the Lac de Gras style kimberlite pipes in Canada (Scott Smith 2008).

\section{Specific features of South Pipe}

The South Pipe is dominated by broadly massive to weakly bedded volcaniclastic kimberlite (VK) units. Although bedding is locally observed, the bedding is typically not traceable between drill holes or extensive mining faces. The bedding appears disrupted in many areas and the bedded zones are often bounded by joints showing slickenside movement (post emplacement). The core domain is dominated by the VK unit at higher levels which transitions into the newly described 'autholith-rich' VK unit 
(AVK). The rim domain is dominated at higher levels by the quartz-rich volcaniclastic kimberlite (QVK) which is identified by elevated levels of free quartz grains. It occurs on the margins of the pipe, is steeply dipping, often sheared and includes fragments of crystal tuffs and occasionally coal clasts. The source of the free quartz is believed to be from Karoo sandstones and Waterberg arkoses present at surface during the eruption of the South Pipe kimberlite.

\section{Specific features of Centre Pipe}

The unique feature when compared to the other pipes is the presence of a large wedge of quartzitic shale and dolomite breccia (>80\% average dilution) on the south western portion of the pipe. At depth $(\sim 1000 \mathrm{~m})$, these breccias include kimberlite breccia which contains $>50 \%$ country rock fragments. The contact between the breccias and the rest of the pipe infill is sharp and dilution drops within a few metres to levels typically $<15 \%$. The internal nature of the breccias including the jigsaw locking of many of the fragments, together with the very steep and sharp nature of the breccia/VK contact, is consistent with a collapse mechanism during the explosive venting of magma at depth (as opposed to breccias formed by collapsing of wall rock into a deep open crater). The process that formed these breccias may be seen as analogous to a block caving mechanism whereby, after the expansion event associated with the magmatic explosions and the removal of magma from depth, the country rock mass is no longer supported and collapses downwards. The collapse front then propagates upwards from the depth level of the explosive excavations. Within this package of breccias, kimberlite infilling is locally observed (post breccia formation). The kimberlite contains abundant fragments of the local host country rock breccia and has coherent magmatic textures in core specimens. Petrography (Skinner, pers. comm. 2012) has confirmed that this kimberlite breccia infill is largely an intrusive event and not fragmental. Locally, however, fragmental textures (including the presence of highly rounded locally derived clasts) are observed in contact with the country rock and further away from the contact, magmatic textures are observed. These macro observations are similarly confirmed by the petrographic descriptions by Skinner, pers. comm. (2012). The interpretation of these features is that initial intrusion of late stage kimberlite melt interacted with limited water ingress within the breccias. This produced steaming discharge, fragmenting the kimberlite melt and aggressively rounding the trapped clasts during the gaseous discharge. Once the limited supply of water was removed through the gas discharge, the remaining kimberlite intruded and inflated the breccia unit. Previous spinel chemistry studies (Stiefenhofer pers. comm. 2007) and a recent study from Phase 2 samples (Mmualefe, pers. comm, 2014) have demonstrated that the kimberlite within the dolomite breccias (part of the KBW_DM facies), appear to be subtly distinct from the VK (Volcaniclastic Kimberlite). Local late-stage macrocrystic dykes (typically $<1 \mathrm{~m}$ in width) are observed in the south western quadrant of the Centre Pipe in particular.

\section{Specific features of North Pipe}

The North Pipe consists of 3 broad zones: the upper core, the lower core and the rim zones. The upper core zone includes the mined out oxidized kimberlite $(\mathrm{OK})$ and reworked volcaniclastic kimberlite $(\mathrm{RVK}(\mathrm{N}))$ units. Both of these units are classified as volcaniclastic kimberlites with the OK displaying high levels of oxidation and associated weathering. The $\mathrm{RVK}(\mathrm{N})$ unit was the dominant unit in the upper core domain of North Pipe and the spinel chemistry indicates that this unit is thought to be petrologically distinct from the PK and VK units in the lower core domain (Stiefenhofer, pers. comm. 2007). As it completely overlies the lower core domain it is believed to be the final volcanic expression of the North Pipe. The rim zone is dominated by volcaniclastic kimberlite (VK) that has been reworked with minor sandstone breccia units on the margins. Although this VK unit has many similarities to the VK units in Centre and South Pipes, it often displays a finer grain size, higher ash content and locally displays well developed/preserved bedding and laminations. The bedding is typically steeply dipping (>45 degrees) and locally, adjacent to the pipe margins, steepens to $>60$ degrees. A particularly finegrained ash-dominated VK was identified in several drill holes and represents a unit that is dominated by ashy VK interbedded with 'normal' VK. The lower North core domain is dominated by pyroclastic kimberlite (PK) which is unique within the context of the Jwaneng kimberlite pipes. The pyroclastic kimberlite is identified by its hard, dark competent physical appearance together with the relatively high 
levels of tightly packed juvenile fragments, abundant olivine macrocrysts and phenocrysts and relatively low levels of lithic dilution and ash. The PK is moderately to well bedded and often clast supported in comparison to the poorly sorted and matrix supported VK unit. Three principal varieties of PK were identified by Webb et al. (2003) and were modelled into the two units: PKa and PKbc units. The primary distinction is that the PKa unit shows lower levels of lithic dilution, is very dark, has higher olivine and mantle xenocryst abundances and the presence of highly baked mudstone/shale clasts with associated metasomatism resulting in needle like gypsum/calcite growth (indicating higher emplacement temperatures). The PKbc in contrast is lighter in colour, has higher levels of lithic fragments and is typically less well sorted (with an associated increase in clay content). The PKbc unit shows strong bedding identified by zones of higher lithic content (sometimes course, clast supported beds) that typically grade upwards into cleaner PK (which are occasionally overlain by thin ashy beds). The base of these PKbc units which are relatively lithic rich and often have sub-rounded to well-rounded lithic clasts that become rare away from the base of these units. Recent drilling post 2007 has indicated that the PKa and PKbc are often interbedded and suggest a coeval and cyclical relationship that extends to depth. They have now been incorporated into a single geological unit dominating the core of North Pipe.

\section{Proposed contrasting emplacement models for South/Centre and North pipes}

The emplacement model proposed for South and Centre pipe includes major vent clearing phases removing more than $70 \%$ of country rock volume possibly initiated by phreatomagmatic activity (as suggested by rare accretionary lapilli, and presence of water bearing Karoo sediments), followed by downward propagation of the pipe. The massive VK units rapidly formed during the collapse of ejected material from the explosion columns and associated tuff rings were significantly reworked within the vent during continued eruptive events. Steeply dipping and internally sheared rim units (which incorporate the highest abundance of preserved pre-eruption surface sediments) were formed by incremental downward propagation relative to the core units during repeated discharge events at depth. The volumetrically significant breccia units in Centre Pipe formed by the caving of the pipe wall rock during eruptions at depth and were subsequently inflated by the injection of later kimberlite magma into the breccias with small scale, localized explosive (groundwater assisted) kimberlite fragmentation. The North pipe with its characteristic pyroclastic unit dominating the core of the pipe, is thought to have formed under reduced explosive energy conditions (after the initial vent forming and clearing phase) as seen by lower levels of explosive fragmentation and the sequence of largely fining-upwards primary pyroclastic beds that are locally interbedded with minor ashy beds and which represent a phase of crater infilling produced by multiple discrete eruptive blasts. The lower energy eruptive environment has resulted in enhanced preservation of primary emplacement features within North Pipe and may indicate reduced groundwater sourcing during eruptions (due to depressed water table), a lower primary volatile content or reduced magma feed rates.

\section{References}

Brown RJ, Gernon TM, Stiefenhofer J, Field M (2008) Geological constraints on the eruption of the Jwaneng Centre kimberlite pipe, Botswana. Journal of Volcanology and Geothermal Research 174:195208

Kinney PD, Compston W, Bristow JW, Williams IS (1989) Archean mantle xenocrysts in a Permian kimberlite: two generations of kimberlitic zircon in Jwaneng DK2, southern Botswana. In: Ross N (ed) Kimberlites and related rocks, Geol. Soc. Australia, pp 833-842

Webb KJ, Stiefenhofer J, Field M (2004) Overview of the geology and emplacement of the Jwaneng DK2 kimberlite, Southern Botswana. $8^{\text {th }}$ International Kimberlite Conference, Long Abstract.

Skinner EMW, Marsh JS (2004) Distinct kimberlite classes with contrasting eruption processes. Lithos 76:183-200. 
- 4 - 